\title{
Organ transplantation and chronic disturbances in the health condition of the population- challenges and perspectives
}

\section{Przeszczepianie narządów i chroniczne zaburzenia stanu zdrowia populacji - wyzwania i perspektywy}

\author{
ARZU KADER HARMANCI SEREN ${ }^{1}$ \\ ${ }^{1} \mathrm{PhD}, \mathrm{RN}$, Assoc. Professor, Department of Nursing Management, Hamidiye Faculty of \\ Nursing, University of Health Sciences, Istanbul / Turkey
}

DOI: http://dx.doi.org/10.21784/IwP.2020.024

ISSN: 2451-1846

\begin{abstract}
End-stage organ failure cases are increasing around the World. Especially chronic kidney failure has been becoming a worldwide epidemic. Although available medical technology and human health resources capacity is enough to transplant organs and tissues to patients diagnosed with end-stage organ failure, many people cannot access the transplantation services because of economic reasons and organ shortage. Thus, health care professionals should focus on preventing chronic organ failures besides increasing the organ donor pool.
\end{abstract}

Keywords: organ failure; organ transplantation; organ donation; preventive health programs; preventative medicine. 


\section{Streszczenie}

Na całym świecie rośnie liczba przypadków końcowej niewydolności narządów. Szczególnie przewlekła niewydolność nerek staje się ogólnoświatową epidemią. Chociaż dostępna technologia medyczna i zasoby ludzkie wystarczają do przeszczepu narządów i tkanek pacjentom, u których zdiagnozowano schyłkową niewydolność narządów, wiele osób nie może uzyskać dostępu do usług transplantacyjnych z powodów ekonomicznych i niedoboru narządów. Dlatego pracownicy służby zdrowia powinni skupić się na zapobieganiu przewlekłej niewydolności narządów, a nie tylko na zwiększaniu puli dawców narządów.

Słowa kluczowe: niewydolność narządów; przeszczepianie narządów; dawstwo narządów; profilaktyczne programy zdrowotne; medycyna zapobiegawcza.

\section{Introduction}

Efforts to remove an organ that does not function in the human body and replace it with a new and functioning one have a long history in medical history. According to the well-known narrative, Saints Cosmas and Damian, who were serving in a Roman province of Syria, amputated the patient's right leg and transplanted him a healthy leg from a deceased male [1]. This narrative and many others have been evidence that human beings had imagined transplant organs from humans to other humans hundreds of years ago. However, organ transplantation could be possible via the development of modern medicine in the past century [2]. Today, although available medical technology and capacity are enough to transplant organs and tissues, many people may not be transplanted because of organ shortage and barriers to access transplantation services $[3,4]$. Thus, health care professionals should focus on preventing chronic organ failures besides increasing the organ donor pool. 


\section{Organ and tissue transplantations}

Organ transplant surgeries are one of the treatment options preferred in chronic kidney failure and improve patients' quality of life considerably compared to other options in different aspects $[5,6]$. Those operations are the only treatment option to keep alive the patient with severe liver, lung, and heart failures. In recent years, apart from solid organ transplants, arm and face transplant surgeries called composite tissue transplantation can also be performed successfully [7]. Organ transplant surgeries, which are better treatment methods in terms of both quality of life and cost, unfortunately, cannot be performed in a number to meet the needs.

Organ transplant operations can be performed with organs obtained from living donors, deceased donors diagnosed with brainstem death, and non-heart-beating donors. Although Istanbul Declaration recommended to transplant organs from deceased donors firstly $[8,9]$, organ transplantation operations are performed mostly by living donors [10] because of cultural values or religious beliefs in Eastern societies [11], even it is allowed to transplant organs from deceased donors legally.

\section{Which points are we focusing on?}

Through the considering countries global data, it is clear that chronic kidney failure has become a worldwide epidemic with its impact on a massive population in the Global scale [12]. In the annual report published by the Turkish Society of Nephrology, it is stated that only in 2019, 9,630 new hemodialysis and 1,109 peritoneal dialysis patients were added to the patients who needed renal replacement therapy [13]. Chronic kidney failure prevalence was reported between 11 to $13 \%$ in Global scale according to the results of a comprehensive meta-analysis [14]. It can be said that chronic kidney failure has a high prevalence based on the aforementioned data above. 
Although the problem has been getting serious, studies and reports are still mostly focusing on increasing safe transplantation interventions, ensuring the provision of care and follow-up of living donors and transplant recipients $[15,16]$.

\section{Which points should we focus on?}

Previous studies also reported significant variabilities between the regions based on the current capacity for kidney care throughout the world. There were significant gaps among the countries according to the capacity of health care services and workforce [17]. Those numbers and findings should warn the global medical society about thinking on different aspects except from enlarging the donor pool and increasing of the number of transplant operations. It may be claimed that with this progress it will not be possible to supply enough number of organs which demanded in between a few decades later.

Although the Declaration of Istanbul clearly states that "Governments should develop and implement ethically and clinically sound programs for the prevention and treatment of organ failure, consistent with meeting the overall healthcare needs of their populations." [8,16], decision makers of the countries and health care professionals mostly focus on the other aspects rather than preventing strategies..

Today, more disciplines should study in collaboration in the fight against chronic diseases. For coping with the chronic diseases which cause organ failure, health authorities of the countries and governments should develop strategies to implement an international action against chronic diseases especially in low and middle-income countries [18]. Multidisciplinary international committees should work on the issue aiming preventing and management of the diseases that cause end stage organ failure. 


\section{Conclusion}

Organ transplantation is one of the essential medical treatments to cope with chronic organ failures. However, the increasing number of patients who need organ transplantations and global organ shortage problems should direct healthcare professionals not only to treat the diseases but also to prevent them more. Multidisciplinary studies focused on strategy development are recommended in this topic.

Acknowledgement: The manuscript was presented as an oral abstract in the International Virtual Conference- Interdisciplinary Approach Towards Chronic Patients and Challenges in Today's Transplantology held on 23 October 2020 at the State University of Applied Sciences in Wloclawek

\section{Bibliografia/Bibliography}

1. Friedlaender GE., Friedlaender LK. Saints Cosmas and Damian: patron saints of medicine. Clinical Orthopaedics and Related Research. 2016; 474(8): 1765-1769.

2. Hatzinger M., Stastny M., Grützmacher P., Sohn M. The history of kidney transplantation. Der Urologe. A. 2016; 55(10):1353-1359.

3. Cantarovich F. Organ Shortage, Will Peoples Knowledge be a Path to the Solution?. Nursing and Health Care. 2019; 4: 44-49.

4. Taylor DM. et al. Limited health literacy is associated with reduced access to kidney transplantation. Kidney International. 2019; 95.5: 1244-1252.

5. Axelrod DA., et al. An economic assessment of contemporary kidney transplant practice. American Journal of Transplantation, 2018, 18(5): 1168-1176. 
6. Shingde R, et al. Relative survival and quality of life benefits of pancreas-kidney transplantation, deceased kidney transplantation and dialysis in type 1 diabetes mellitus-a probabilistic simulation model. Transplant International. 2020; 33(11): 1393-1404.

7. Hettiaratchya S, Randolphb MA, Petitc F, Leed WPA, Butler PEM. Composite tissue allotransplantation-a new era in plastic surgery? The British Association of Plastic Surgeons. 2004; 57: 381-391.

8. The Declaration of Istanbul 2018 Edition. https://www.declarationofistanbul.org/images/Policy_Documents/2018_Ed_Do/2018_Edition_of_the_Declaration_of_Istanbul_Final.pdf

9. Steering Committee of the Istanbul Summit. Organ trafficking and transplant tourism and commercialism: The Declaration of Istanbul. The Lancet. 2008; 372(9632): 5-6.

10. Gómez MP., Irazábal M M., Manyalich M. International Registry In Organ Donation And Transplantation-2019 Worldwide Data. Transplantation, 2020; 104(S3): S272.

11. Demırkiran O., Bozbay S., Elmaagac M., Agkoç M. Religious and Cultural Aspects of Organ Donation in the Turkish Population. In Transplantation proceedings. 2019; 51(7): 2158-2162.

12. Boukenze B., Haqiq A., Mousannif H. Predicting chronic kidney failure disease using data mining techniques. In International Symposium on Ubiquitous Networking. Springer, Singapore. 2016: 701-712.

13. Suleymanlar G, Ateş K, Seyahi N. Registry of The Nephrology, Dialysis and Transplantation In Turkey-Registry 2019. Ankara. 2020. http://www.nefroloji.org.tr/folders/file/registry_2019.pdf

14. Hill NR., Fatoba ST., Oke JL., Hirst JA., O'Callaghan CA, Lasserson DS., Hobbs FR. Global prevalence of chronic kidney disease-a systematic review and meta-analysis. PloS one. 2016; 11(7): e0158765. 
15. Janki S. et al. Long-term prognosis after kidney donation: a propensity score matched comparison of living donors and non-donors from two population cohorts. European Journal of Epidemiology.2020.

16. Delmonico FL. The implications of Istanbul Declaration on organ trafficking and transplant tourism. Current Opinion in Organ Transplantation, 2009; 14(2): 116-119.

17. Bello AK., et al. Assessment of global kidney health care status. Jama. 2017; 317(18): 1864-1881.

18. Geneau R. et al. Raising the priority of preventing chronic diseases: a political process. The Lancet, 2010; 376(9753): 1689-1698. 